\title{
Quaderni
}

QUADERNI Communication, technologies, pouvoir

75 | Printemps 2011

Le Parlement face aux TIC

\section{La politique symbolique de la CNIL}

\section{David Forest}

\section{(2) OpenEdition \\ Journals}

\section{Édition électronique}

URL : http://journals.openedition.org/quaderni/709

DOI : 10.4000/quaderni.709

ISSN : 2105-2956

\section{Éditeur}

Les éditions de la Maison des sciences de l'Homme

\section{Édition imprimée}

Date de publication : 5 avril 2011

Pagination : 17-27

\section{Référence électronique}

David Forest, "La politique symbolique de la CNIL », Quaderni [En ligne], 75 | Printemps 2011, mis en ligne le 05 avril 2013, consulté le 04 mai 2019. URL : http://journals.openedition.org/quaderni/709 ; DOI : 10.4000/quaderni.709

Ce document a été généré automatiquement le 4 mai 2019.

Tous droits réservés 


\title{
La politique symbolique de la CNIL
}

\author{
David Forest
}

\section{NOTE DE L'ÉDITEUR}

L'auteur n'a pas donné son accord pour la diffusion électronique de son article.

\section{RÉSUMÉS}

Cet article propose d'analyser sur la longue durée la politique symbolique de la CNIL (Commission nationale de l'informatique et des libertés) en identifiant trois périodes. Dans un premier temps, la Commission participe à la « mise en invisibilité » et à distance d'un État perçu comme la principale menace à l'endroit des libertés. Un deuxième temps marque son retour en visibilité qui se manifeste par un impératif de réglementation policière. Parallèlement, la CNIL accompagne le transfert d'hégémonie normative vers l'entreprise à la faveur de la déréglementation. La dernière période est marquée par un affaiblissement de la fonction de mise à distance de la Commission qui doit en conséquence sécréter des signes de légitimité par la production d'images symboliques consensuelles comme autant de défenses immunitaires à l'égard de l'exécutif, dont sa survie dépend, aussi bien qu'à l'endroit des citoyens.

This article aims at analyzing throughout a long period of time the policy symbolic system of the CNIL (The National Commission for computer and freedoms) by identifying three stages. Initially, the Commission took part in the "setting of invisibility" and keeping the State considered as the principal threat for freedoms at a distance. The second stage put in visibility the State meanwhile a police regulation is reinforced. In parallel, the CNIL went with the transfer of normative hegemony towards the company pursuant to the deregulation doctrine. The last stage is distinguished by a weakening of the remoteness function of the Commission which must 
consequently secrete signs of legitimacy by producing consensual symbolic images systems as immunizing defenses with regard to the executive whose its survival depends as well as to the citizens

\section{AUTEUR}

\section{DAVID FOREST}

Docteur en science politique (Paris I)

Avocat

CERDI (Paris I / Paris XI)

LAS (Rennes II) 